\title{
JAK INTERPRETOWAĆ NORMY KODEKSOWE? PRAWO KANONICZNE WYRAZEM JEDNOŚCI KOŚCIOŁA
}

Stowa klucze:

Biskup Rzymski, interpretacja, jedność, prawo partykularne, prawo powszechne, zasady

Treść:

I. Sobór Watykański II na temat jedności porządku prawnego Kościoła

II. Zasady dotyczące interpretacji kanonów KPK

III. Interpretacja prawa kanonicznego w przemówieniach rotalnych Biskupów Rzymskich

IV. Czy można zmienić kodeksowy emerytalny wiek proboszcza?

Od promulgacji posoborowego Kodeksu Prawa Kanonicznego przez papieża Jana Pawła II minęło już przeszło ćwierć wieku. Miniony czas charakteryzuje się niewielkimi nowelizacjami ustawodawstwa kodeksowego, wprowadzonymi tak przez Jana Pawła II, jak i przez Benedykta XVI ${ }^{1}$. Ponadto, jak powszechnie wiadomo, trwaja prace nad nowym prawem karnym i należy się spodziewać, że zostanie opublikowana cała nowa księga dotycząca kanonicznego prawa karnego, która zastąpi obowiązującą; z kolei na potrzeby kanonicznego procesu małżeńskiego została wydana długo oczekiwana oraz praktycznie bardzo potrzebna instrukcja procesowa Dignitas connubii $(2005)^{2}$. Natomiast codzienne życie Kościoła dostarcza różnych informacji, że kanony Kodeksu Jana Pawła II są nieustannie interpretowane,

* Ks. Tomasz Rozkrut, profesor nauk prawnych, zastępca wikariusza sądowego w Sądzie Diecezjalnym w Tarnowie, autor wielu książek i artykułów z dziedziny prawa kanonicznego.

${ }^{1}$ Por. Jan Paweł II, Motu proprio „Ad tuendam fidem”, AAS 90(1998), s. 457-461; Benedykt XVI, Motu proprio „Omnium in mentem”, AAS 102(2010), s. 8-10.

2 Por. Pontificium Consilium de legum textibus, Instructio servanda a tribunalibus dioecesanis et interdioecesanis in pertractandis causis nullitatis matrimonii, Città del Vaticano 2005. 
w dużej mierze przez sądownictwo Kościoła (w szczególności dotyczy to materialnego prawa małżeńskiego oraz formalnego prawa procesowego) oraz praktykę kurii diecezjalnych, jak i przez stosowanie prawa przez kancelarie parafialne; naturalnie należałoby tutaj także podkreślić znaczącą oraz dominującą rolę w stosowaniu prawa przez praktykę Kurii Rzymskiej (tzw. stylus oraz praxis Curiae Romanae). Do tego należy dodać działalność ustawodawczą poszczególnych biskupów diecezjalnych oraz konferencji biskupów, wśród których należałoby przede wszystkim wskazać Konferencje Biskupów Włoch, która niewątpliwie dla pozostałych episkopatów Kościoła katolickiego winna pozostawać wzorem aplikowania prawa powszechnego na poziomie lokalnym, naturalnie $\mathrm{w}$ granicach wyznaczonych przez ustawodawcę powszechnego ${ }^{3}$. Nie można także w tym wyliczaniu pominąć ustawodawstwa partykularnego wydanego przez posoborowe synody partykularne oraz diecezjalne; niewątpliwie także swoistym zbiorem prawa kanonicznego pozostaje szeroko rozumiane posoborowe prawo zakonne.

Mówiąc na temat działalności legislacyjnej biskupów Kościoła w Polsce, warto odnotować dość swoisty, a jednocześnie krytyczny głos bp. T. Pieronka, który w wywiadzie opublikowanym w 2011 roku stwierdził: „Wielu biskupów uważa, że ma władzę większą od papieża. Nie leży w ich mocy zwalnianie proboszczów przed wiekiem emerytalnym, więc posyłaja do proboszcza siepaczy, którzy dyskutują z nimi, póki nie podpiszą rezygnacji” ${ }^{4}$. Ponieważ poruszony, także i w tej wypowiedzi, problem dotyczący ewentualnej możliwości zmiany przez ustawodawcę partykularnego wieku emerytalnego wyznaczonego kodeksowo dla proboszczów na siedemdziesiąt pięć lat ${ }^{5}$, a który jest także podnoszony w dyskusji przez polskich kanonistów, warto np. przypomnieć publiczną dyskusję na ten temat podczas Konferencji Stowarzyszenia Kanonistów Polskich z września 2010 roku w Toruniu. Chciałbym się do tego problemu odnieść poprzez wskazanie jak należy właściwie interpretować kanony obowiązującego Kodeksu, podejmując to zagadnienie nie jednostronnie, ale w relacji do dwóch zagadnień, $\mathrm{tj}$. w relacji do kanonicznego procesu małżeńskiego oraz wskazanego powyżej zagadnienia dotyczącego ewentualnej możliwości zmiany wieku emerytalnego proboszcza. Będzie to zasadniczo krótka refleksja naukowa, takie jest założenie powyższej wypowiedzi, naturalnie bez krytycznego odnoszenia się do konkretnej praktyki sądowej oraz administracyjno-prawnej, a niewątpliwie wydaje się, że z punktu praktycznego jest ona ważna i być może spowoduje otwarcie szerszej dyskusji, która winna także wskazać, że prawo w Kościele

\footnotetext{
${ }^{3}$ Por. J.M. de Agar, L. Navarro, Legislazione delle Conferenze Episcopali complementare al C.I.C., Roma 2009.

${ }^{4}$ T. Pieronek, Zejście z piedestału, ,Tygodnik Powszechny” 23 (5 VI 2011), s. 17.

5 „Proboszcz, po ukończeniu siedemdziesiątego piątego roku życia, jest proszony o złożenie zrzeczenia się urzędu na ręce biskupa diecezjalnego, który zważywszy wszystkie okoliczności osoby i miejsca, powinien zadecydować o przyjęciu lub odłożeniu zrzeczenia" (KPK, kan. $538 \S 3$ ).
} 
nie powinno być postrzegane jako instrument władzy czy rządzenie, ale bardziej jako służba człowiekowi ${ }^{6}$. Tym bardziej, że mamy do czynienia z zagadnieniem jednocześnie trudnym oraz delikatnym, którym jest właściwa interpretacja oraz stosowanie normy kanonicznej, bowiem z jednej strony dotyczą one właśnie człowieka oraz jego różnych sytuacji życiowych, z drugiej zaś wierności normie prawnej, która nie tylko winna być postrzegana jako sprawiedliwa oraz słuszna w perspektywie dobra wspólnego, ale jednocześnie z taką intencją winna być stosowana ${ }^{7}$.

\section{SOBÓR WATYKAŃSKI II NA TEMAT JEDNOŚCI PORZĄDKU PRAWNEGO KOŚCIOŁA}

Wprawdzie Sobór Watykański II nie zajął się wprost tworzeniem nowego prawa kodeksowego, którego ostateczna reforma - ze zrozumiałych względów - została przesunięta na okres posoborowy, niemniej jednak w jego doktrynie na temat kolegialności episkopatu możemy znaleźć istotne z punktu doktrynalnego wypowiedzi na temat relacji prawo powszechne prawo partykularne, które przede wszystkim zostały zawarte w Konstytucji dogmatycznej o Kościele Lumen gentium.

Mówiąc na temat kolegialnego współdziałania biskupów oraz ich władzy, należy za myślą Lumen gentium (nr 23) podkreślić, a zarazem wskazać, że Kolegium Biskupów wraz z biskupem rzymskim reprezentuje cały Kościół, natomiast poszczególni biskupi w swoich Kościołach przedstawiają Kościół powszechny, a powierzony Kościół z kolei na poziomie Kolegium Biskupów, czyli na poziomie Kościoła powszechnego. Stąd można mówić o podwójnej misji biskupa - względem powierzonego Kościoła (ma ona charakter prawny na podstawie misji kanonicznej otrzymanej od biskupa rzymskiego) oraz względem całego Kościoła, która jest wynikiem przynależności do Kolegium Biskupów i trzeba ją postrzegać bardziej jako obowiązek moralny niż jako zobowiązanie prawne.

Konkretne wyrazy solidarności między biskupami wyrażają się przez jedność wyznawanej, strzeżonej i rozpowszechnianej wiary, przez troskę o dyscyplinę w Kościele (czyli konkretnie przez zachowywanie tych samych praw dyscyplinarnych oraz liturgicznych obowiązujących w całym Kościele powszechnym); mówiąc krótko, biskupi „mają obowiązek umacniać i strzec jedności wiary i wspólnej dyscypliny całego Kościoła"8 oraz okazywać miłość (caritas) względem najbardziej potrzebujących: ubogich, cierpiących, prześladowanych ze względu na sprawiedliwość.

\footnotetext{
${ }^{6}$ Por. M. Giordano, Interpretazione della legge e carità, w: AA. VV., Il diritto della Chiesa. Interpretazione e prassi, Città del Vaticano 1996, s. 7.

${ }^{7}$ Por. Paweł VI, Ad Praelatos Auditores et Officiales Tribunalis S. R. Rotae novo litibus iudicandis ineunte anno coram admissos (28 ianuarii 1972), AAS 64(1972), s. 205.

${ }^{8}$ Sobór Watykański II, Konstytucja dogmatyczna o Kościele „Lumen gentium”, nr 23.
} 
A zatem, stosując doktrynę soborową w praktyce, należy powiedzieć, że jeżeli biskup podejmowałby nieuprawnioną działalność ustawodawczą, czy to w dziedzinie powszechnej dyscypliny prawnej, czy też obowiązującego porządku liturgicznego, nie ulega wątpliwości, że w ten sposób szkodziłby nie tylko swojemu Kościołowi partykularnemu, ale także pośrednio Kościołowi powszechnemu, przede wszystkim poprzez fakt szkodliwego oddziaływania na kościelne ius oraz communio. Biskup-ustawodawca winien zawsze pamiętać o niedyskusyjnej przewadze prawa powszechnego nad prawem partykularnym, co z kolei jest wynikiem w eklezjologii łacińskiej, jak również $\mathrm{w}$ praktyce ostatniego tysiąclecia, dominacji Kościoła powszechnego nad tym partykularnym ${ }^{9}$. Zadaniem bowiem tak prawa powszechnego, jak i tego partykularnego jest historyczne zagwarantowanie, że jedność oraz pluralizm obecne w Kościele Chrystusowym realizują w sposób możliwie najlepszy soborową zasadę eklezjologiczną in quibus oraz ex quibus; ,wymaga to z jednej strony, aby uniwersalne prawo kanoniczne mogło być bez trudności stosowane przez poszczególne Kościoły partykularne; z drugiej strony, że prawo partykularne, poprzez niewłaściwy proces inkulturacji, nie będzie różne od takiego samego prawa innych Kościołów, które konstytuują wymiar powszechny Kościoła Chrystusowego i tworzą przez to także prawo uniwersalne" ${ }^{\prime \prime}$.

Wskazana przez Lumen gentium kolegialna troska o Lud Boży ma obejmować także każdą inną działalność wspólnotową na rzecz Kościoła, ze szczególnym odniesieniem do wzrostu wiary oraz rozpowszechniania Ewangelii, ma to się łączyć z mądrymi oraz roztropnymi rządami w powierzonym Kościele - można powiedzieć, że w ten sposób biskup najlepiej wypełnia swoje zadanie wynikające $\mathrm{z}$ sukcesji apostolskiej. Biskup zatem na różne sposoby przyczynia się do tworzenia ogólnokościelnego dobra, w szczególności odnosi się to do rozszerzania wiary poprzez działalność misyjną.

W tak ukazanym kontekście soborowym, odwołując się także do obowiązujących norm kodeksowych, należy jasno powiedzieć, że władza biskupa diecezjalnego nie ma charakteru, jak to się popularnie mówi, ,absolutnego", bowiem jak jasno stanowi kan. $381 \S 1$ władza ta jest dość precyzyjnie określona jako „wymagana (requiritur)” do wykonywania powierzonego urzędu: „Biskupowi diecezjalnemu w powierzonej mu diecezji przysługuje wszelka władza zwyczajna, własna i bezpośrednia, jaka jest wymagana do jego pasterskiego urzędu, z wyłączeniem tych spraw, które na mocy prawa lub dekretu Papieża są zarezerwowane najwyższej lub innej władzy kościelnej”. W konsekwencji, biskup ten nie może udzielać wszystkich dyspens, bo niektóre są właśnie zarezerwowane dla Stolicy Apostolskiej; ponadto w żadnym wypadku nie może zmienić ani prawa karnego, ani tego procesowego ${ }^{11}$;

9 Por. E. Corecco, „Ius universale” „ius particulare”, w: G. Borgonovo, A. Cattane o (red.), Ius et communio. Scritti di Diritto Canonico, t. 1, Lugano 1997, s. 550.

${ }^{10}$ Tamże, s. 565.

${ }^{11}$ KPK, kan. $87 \S 1$. 
co więcej, ustawodawca powszechny postanowił, że wszystkie sądy Kościoła są regulowane tymi samymi kanonami, z zachowaniem jedynie norm Trybunałów Stolicy Apostolskiej ${ }^{12}$.

Także ograniczona jest władza ustawodawcza biskupa. Kanon $135 \S 2$ stanowi, że „władza ustawodawcza winna być wykonywana w sposób przepisany prawem, a ta, którą posiada ustawodawca kościelny, niższy od władzy najwyższej, nie może być ważnie delegowana, chyba że coś innego prawo wprost zastrzega. Niższy prawodawca nie może ważnie wydać ustawy przeciwnej wyższemu prawu". W ten sposób biskup rzymski, mocą swojego urzędu, może zarezerwować tylko dla siebie albo innemu autorytetowi wybrane sprawy, przede wszystkim mając na względzie dobro Kościoła lub wiernych, ograniczając $w$ ten sposób sprawowanie władzy przez biskupów ${ }^{13}$ : „Władza ta, którą w imieniu Chrystusa osobiście sprawują jest własna, zwyczajna i bezpośrednia, choć jej wykonywanie jest kierowane w ostatecznej instancji przez najwyższą władzę Kościoła, i ze względu na dobro Kościoła lub wiernych może być w pewnej mierze ograniczane" ${ }^{\prime 4}$. Jeszcze precyzyjniej zostało to wyrażone w Dekrecie o pasterskich zadaniach biskupów w Kościele Christus Dominus (nr 8), w którym czytamy na temat ograniczenia władzy ustawodawczej biskupów, którym ,jako następcom Apostołów, w powierzonych im diecezjach przysługuje, siłą rzeczy, cała władza zwyczajna, własna i bezpośrednia, która jest konieczna do pełnienia ich pasterskich zadań, z zachowaniem jednak zawsze we wszystkim władzy, którą na mocy swego urzędu posiada biskup rzymu w zakresie zastrzegania spraw sobie lub innej władzy". Z doktryny Soboru Watykańskiego II, zaszczepionej później w życiu Kościoła przez normy kodeksowe, wynika zatem ważny oraz konkretny wniosek, mianowicie - biskup, sprawując władzę ustawodawczą, ma mieć na uwadze nie tylko prawo Boże, ale także prawo kościelne, zarówno to powszechne, jak i to promulgowane przez synody plenarne, partykularne czy przez konferencje biskupów ${ }^{15}$.

Eugenio Corecco, wybitny kanonista i biskup Lugano w Szwajcarii (1931-1995), wskazuje, że norm kodeksowych, które otwierają przestrzeń dla prawa partykularnego, jest aktualnie pięćdziesiąt sześćc ${ }^{16}$; przy czym zaznaczył on, że jednak w Kodeksie z 1983 roku przeważa myśl, aby bardziej zagwarantować jedność niż pluralizm Kościoła, a należałoby dodać, że jest to wynikiem takiego, a nie innego odczytania myśli soborowej przez kościelnego ustawodawcę ${ }^{17}$.

Natomiast watykańska instrukcja De Synodis dioecesanis agendis (1997) wylicza wprost w swoim dodatku (Additamentum ad instructionem

\footnotetext{
${ }^{12}$ KPK, kan. 1402.

${ }^{13}$ E. Corecco, ,Ius universale”, ,ius particolare”, dz. cyt., s. 560.

${ }^{14}$ Sobór Watykański II, Konstytucja dogmatyczna o Kościele „Lumen gentium”, nr 27.

${ }^{15}$ Por. E. Corecco, ,I Ius universale”,, ius particolare”, dz. cyt., s. 561.

${ }^{16}$ Por. tamże, s. 572.

${ }^{17}$ Por. tamże, s. 573.
} 
de Synodis dioecesanis agendis), będącym zarazem praktyczną pomoca techniczna, obszary powierzone przez Kodeks Prawa Kanonicznego władzy ustawodawczej biskupa diecezjalnego (Pastoralia munia quae Codex Iuris Canonici concredit legum ferendarum potestati Episcopi dioecesani), wyróżniając kompetencji w munus docendi, munus sanctificandi oraz munus pascendi ${ }^{18}$. Przy czym dodatek ów jasno zaznacza, powołując się na kan. $135 \S 2$ oraz na samą instrukcję ${ }^{19}$, że biskup jest wezwany w wykonywaniu władzy ustawodawczej do zachowania oraz respektowania prawa wyższego (ut ius superius observet ac revereatur), a ewentualny dekret synodalny wbrew prawu wyższemu należy uważać za nieważny ${ }^{20}$.

\section{ZASADY DOTYCZACCE INTERPRETACJI KANONÓW KPK}

Kanoniczne normy prawne, podobnie jak każdy porządek prawny, są przedmiotem nieprzerwanej interpretacji, która stanowi autonomiczny oraz niezależny fenomen, związany z każdym porządkiem prawnym ${ }^{21}$. Kodeksowe Normy ogólne podają między innymi, następujące zasady dotyczące stosowania prawa kodeksowego ${ }^{22}$ :

1. Ustawom powszechnym podlegają na całym świecie wszyscy (ubique terrarum omnes), dla których zostały wydane ${ }^{23}$; a zatem mogą one dotyczyć nie tylko wszystkich ochrzczonych (in genere - jak np. powszechne wezwanie do prowadzenia życia świętego, o którym mówi kan. 210), ale także tylko pewnych kategorii osób (np. duchownych, małżonków), stąd też ustawodawca użył zwrotu pro quibus latae sunt ${ }^{24}$.

2. Ustawy $w$ sposób autentyczny interpretuje prawodawca oraz ten, komu zlecił on władzę autentycznego interpretowania ${ }^{25}$; w tym celu Biskup Rzymski powołał specjalną radę (aktualna jej nazwa: Papieska Rada

${ }^{18}$ Por. Enchiridion Vaticanum, t. 16, s. 182-195.

19 „Erit ex iure invalidum fortuitum synodale decretum iuri superiori contrarium” (V, 4), w: Enchiridion Vaticanum, t. 16, s. 180

${ }^{20}$ Por. Enchiridion Vaticanum, t. 16, s. 184.

${ }^{21}$ Por. A. Stankiewicz, Interpretazione della legge con riferimento alle funzioni della potestà ecclesiastica, „Ephemeridis iuris canonici” 25, 1-4(1979) 23.

${ }^{22}$ Por. T. Pawluk, Prawo kanoniczne wedlug Kodeksu Jana Pawła II, Olsztyn 1985, t. 1, s. $229-232$.

${ }^{23}$ KPK, kan. $12 \S 1$.

${ }^{24}$ Por. L. Chiappetta, Il codice di diritto canonico, Napoli 1988, t. 1, s. 26.

${ }^{25} \mathrm{KPK}$, kan. $16 \S 1$. Należy jednak pamiętać, że ,interpretacja autentyczna, dokonana w formie ustawy, posiada taką samą moc co ustawa i wymaga promulgacji; jeśli tylko wyjaśnia słowa ustawy same w sobie pewne, wtedy działa wstecz. Gdy ustawę zawęża lub poszerza albo thumaczy wątpliwą, nie działa wstecz” (KPK, kan. 16 § 2); natomiast ,interpretacja dokonana $\mathrm{w}$ formie wyroku sądowego lub aktu administracyjnego w poszczególnej sprawie, nie ma mocy ustawy i wiąże jedynie osoby oraz dotyczy spraw, dla których została wydana" (KPK, kan. 16 § 3). W związku z powyższym możemy mówić o trzech formach interpretacji prawa: 1. „per modum legis”, 2. „,per modum sententiae iudicialis”, 3. „per modum rescripti in re peculiari" (por. A. Stankiewicz, Interpretazione della legge con riferimento alle funzioni della potestà ecclesiastica, dz. cyt., s. 28). 
ds. Tekstów Prawnych), której według Konstytucji apostolskiej Pastor bonus (1988) najważniejszym zadaniem jest interpretacja ustaw kościelnych (art. 154). Ponadto, ,na wniosek zainteresowanych Rada rozstrzyga, czy ustawy partykularne i dekrety ogólne wydane przez ustawodawców niższych od władzy najwyższej są zgodne z powszechnym prawem Kościoła" (art. 158).

Oprócz tego, dużą rolę w interpretacji prawa (w szczególności materialnego prawa małżeńskiego oraz formalnego prawa procesowego) pełni orzecznictwo Trybunałów Apostolskich (tj. Roty Rzymskiej oraz Najwyższego Trybunału Sygnatury Apostolskiej), w szczególności Trybunał Roty Rzymskiej - według Pastor bonus (art. 126) - „troszczy się o jedność orzecznictwa oraz swymi orzeczeniami służy pomocą trybunałom niższych stopni”. Interpretacja prawa dokonana w formie wyroku sądowego ma miejsce poprzez zastosowanie normy generalnej do konkretnego partykularnego wypadku poprzez sprawowanie władzy sądowniczej w Kościele, w celu rozwiązania kontrowersji między osobami, tak fizycznymi, jak i prawnymi, albo w celu deklaracji istnienia lub prawdy spornego faktu ${ }^{26}$. Należy także przypomnieć, iż orzecznictwo to odegrało znaczącą rolę w formowaniu nowych kanonów małżeńskich.

3. Ustawy kościelne należy rozumieć według własnego znaczenia słów, rozważanego w tekście i kontekście ${ }^{27}$; przy czym określenie „własne znaczenie słów" ma walor techniczno-kanoniczny, przede wszystkim jako rezultat wytworzonej tradycji kanonistycznej ${ }^{28}$. Doktryna uczy, odwołując się do kan. 17, że powyższa norma wskazuje na zasadniczą regułę interpretacji kanonów kodeksowych, która się opiera na poznaniu znaczenia słów rozważanego w tekście oraz kontekście ${ }^{29}$.

Warto w tym miejscu wskazać także, że ważnym kryterium dla interpretacji Kodeksu z 1983 roku pozostają dokumenty Soboru Watykańskiego II, jak to wyraźnie wskazał Jan Paweł II w konstytucji apostolskiej Sacrae disciplinae leges (1983) promulgującej nowy Kodeks Prawa Kanonicznego w nr 18: „Narzędzie, jakim jest Kodeks, w pełni zgadza się z naturą Kościoła, jaką zwłaszcza przedstawia nauka Soboru Watykańskiego II brana w całości, ze szczególnym uwzględnieniem jego doktryny eklezjologicznej. Zatem w jakiś sposób ten nowy Kodeks może być pojmowany jako wielki pas transmisyjny przenoszący na język kanonistyczny tę doktrynę, mianowicie soborową eklezjologię. Chociaż nie da się obrazu Kościoła w ujęciu doktryny Soboru doskonale przełożyć na język kanonistyczny, to jednak Kodeks

${ }^{26}$ Por. P.G. Marcuzzi, Le forme dell'interpretazione canonica tra diritto ed equità, w: AA. VV., Il diritto della Chiesa. Interpretazione e prassi, Città del Vaticano 1996, s. 44.

${ }^{27}$ KPK, kan. $16 \S 3$. Ponadto powyższa norma dodaje: ,jeśli pozostaje ono wątpliwe i niejasne, należy uwzględnić miejsca paralelne, gdy takie są, cel i okoliczności ustawy oraz myśl prawodawcy" (tamże).

${ }^{28}$ Por. L. Chiappetta, Il codice di diritto canonico, dz. cyt., s. 36.

${ }^{29}$ Por. P.G. Marcuzzi, Le forme dell'interpretazione canonica tra diritto ed equità, dz. cyt., s. 41 . 
powinien się odnosić do tego obrazu jako pierwotnego wzoru, którego zarys powinien on odpowiednio, o ile to możliwe, z samej swej natury wyrażać".

Ponadto, jeżeli aplikacja wskazanej reguły, nie rozwiązuje zaistniałej wątpliwości, to należy idąc za normą kan. 17, „uwzględnić miejsca paralelne, gdy takie są, cel i okoliczności ustawy oraz myśl prawodawcy”. Szczególną rolę odgrywać będzie w tym procesie poznanie myśli ustawodawcy (mens legislatoris), czyli poznanie partykularnego motywu, który w wykonywaniu przez niego funkcji publicznej, wskazał mu na konieczność ogłoszenia określonego prawa wraz z jego oczekiwaniem w przedmiocie jego zrozumienia oraz stosowania ${ }^{30}$.

W doktrynie wskazuje się, że zadaniem interpretacji jest zatem poznać wolę ustawodawcy zawartą w słowach, czyli wykryć ich sens prawdziwy; mówiąc inaczej, interpretacja zmierza do wykrycia tego, co ustawodawca faktycznie w sposób rozumny postanowił, a nie do tego, co mógł lub powinien był postanowić ${ }^{31}$. Mówiąc inaczej, wola ustawodawcy, jego mens zamknięta w lingwistycznej formie prawnej, według znaczenia przypisanemu jej przez ustawodawcę, stanowiłaby przedmiot interpretacji, o czym między innymi następująco czytamy w Dekrecie Gracjana (c. 11, q. 5, C. XXII): quia non debet aliquis verba considerare, sed voluntatem et intentionem, quia non debet intentio verbis deservire, sed verba intentioni ${ }^{32}$.

\section{INTERPRETACJA PRAWA KANONICZNEGO W PRZEMÓWIENIACH ROTALNYCH BISKUPÓW RZYMSKICH}

Rotalne alokucja, tak Jana Pawła II, jak i Benedykta XVI, zawieraja ważne wskazówki Biskupów Rzymskich, czyli powszechnych i najwyższych ustawodawców, w przedmiocie interpretacji kanonów Kodeksu z 1983 roku. W porządku chronologicznym, jedynie wybrane fragmenty ze wskazanego magisterium, przedstawiają następne zagadnienia:

- wierność nowemu Kodeksowi;

- nie może mieć miejsca subiektywna interpretacja nowych kanonów;

- istnieją ścisłe zasady jak interpretować nowy Kodeks Prawa Kanonicznego;

- niezdolność konsensualna nie może być utożsamiana z rozpadem wspólnoty małżeńskiej;

- obiektywizm ma cechować interpretację prawa.

I tak, Jan Paweł II, przemawiając po promulgacji nowego Kodeksu Prawa Kanonicznego, wskazał w alokucji rotalnej z 1984 roku, że poznaniu nowego prawa kodeksowego ma towarzyszyć wierność; odnosząc się szczególnie do sądownictwa kościelnego, wskazał, że jest to „pierwszy i najważ-

\footnotetext{
${ }^{30}$ Por. L. Chiappetta, Il codice di diritto canonico, dz. cyt., s. 38.

${ }^{31}$ Por. T. Pawluk, Prawo kanoniczne wedlug Kodeksu Jana Pawła II, dz. cyt., s. 229.

${ }^{32}$ A. Stankiewicz, Interpretazione della legge con riferimento alle funzioni della potestà ecclesiastica, dz. cyt., s. 26.
} 
niejszy obowiązek sędziego względem prawa". W dalszej kolejności Jan Paweł II wyjaśnił, że owa wierność polega przede wszystkim na szczerym zaakceptowaniu obowiązującego prawa. Wypowiadając się na temat interpretacji prawa, przypomniał, że interpretacja autentyczna, czyli taka, która deklaruje jego sens ogólny dla całej wspólnoty, jest zarezerwowana ustawodawcy; natomiast odwołując się do obowiązującego kan. $16 \S 3$, przypomniał, że wyrok sądowy jest jedynie dla stron procesowych interpretacją normy prawnej: „Aplikując ją do przypadku konkretnego, sędzia dokonuje interpretacji, która chociaż nie posiada waloru ogólnego, niemniej jednak wiąże strony siłą samego prawa". Przechodząc natomiast do materialnego prawa małżeńskiego, Jan Paweł II zaznaczył, iż w nowym Kodeksie Prawa Kanonicznego, specjalnie w materii zgody małżeńskiej, zostały wprowadzone modyfikacje dzięki orzecznictwu rotalnemu; przy czym zaznaczył, że niektóre kanony, o znacznej wadze w prawie małżeńskim, zostały sformułowane w sposób ogólny i oczekują sukcesywnych precyzyjniejszych określeń, w czym winna pomóc właśnie jurysprudencja rotalna ${ }^{33}$.

Sukcesywnie, w przemówieniu rotalnym z 1986 roku Jan Paweł podkreślił, że niewątpliwie aplikowanie nowego Kodeksu Prawa Kanonicznego powoduje ryzyko interpretacji reformującej, nieprecyzyjnej i niespójnej, szczególnie w przypadkach wyrokowania $\mathrm{z}$ tytułu perturbacji psychicznych powodujących nieważność zgody małżeńskiej, o której mówi kan. 1095, albo też w wypadku podstępu, o którym mówi kan. 1098, czy też w wypadku błędu kondycjonującego wolę według normy kan. 1099; ponadto problem ten dotyczy także interpretacji niektórych nowych norm proceduralnych ${ }^{34}$. Sukcesywnie, szczególnym przedmiotem alokucji rotalnych Jana Pawła II stał się kan. 1095 oraz jego poprawna interpretacja procesowa, co szczególnie miało miejsce w jego słynnych przemówieniach z 1987 oraz z 1988 roku, do których zresztą niedawno nawiązał Benedykt XVI w przemówieniu rotalnym z 2009 roku.

Z kolei w przemówieniu rotalnym z 1993 roku Jan Paweł II uznał za stosowne przywołać niektóre zasady hermeneutyczne dotyczące interpretacji prawa kanonicznego. I tak wskazał, że prawo kościelne ma być, przede wszystkim, rozumiane secundum propriam verborum significationem in textu et contextu consideratam, z czego wynika, że byłoby czymś arbitralnym, więcej nielegalnym i ciężko zawinionym, przypisywanie słowom użytym przez ustawodawcę ich niewłaściwego znaczenia. Od wspomnianych zasad, szczególnie w materii prawa małżeńskiego, nie może się odrywać, bliżej niesprecyzowana humanizacja prawa kanonicznego. Dlatego też Jan Paweł II wskazał, że w aplikacji prawa kanonicznego, trzeba pamiętać o poprawnej znajomości ustawodawstwa Kościoła, nie zapominając przy tym o antropologii

\footnotetext{
${ }^{33}$ Por. Jan Paweł II, Ad Praelatos Auditores S. Romanae Rotae coram admissos (die 26 ianuarii 1984), AAS 76(1984), s. 647n.

${ }^{34}$ Por. Jan Paweł II, Ad Rotae Romanae praelatos auditores coram admissos (die 30 ianuarii 1986), AAS 78(1986), s. 924.
} 
chrześcijańskiej. Albowiem naciaganie prawa kanonicznego do kaprysów albo do pomysłowości interpretacyjnej, w imię dwuznacznej i niezdefiniowanej tzw. zasady humanitarnej, oznaczałoby uśmiercanie nie tylko samej normy kanonicznej, ale przede wszystkim samej godności człowieka. Jako przykład Jan Paweł II podał, że byłoby dużą raną dla stabilności małżeństwa, a tym samym dla jego świętości, gdyby fakt symulacji małżeńskiej nie byłby urzeczywistniany ze strony symulującego, zgodnie z kan. $1101 \S 2$, przez actus positivus voluntatis; czy też, zgodnie z normą kan. 1099, tzw. error iuris odnośnie istotnego przymiotu małżeństwa albo jego godności sakramentalnej, nie przyjąłby takiej intensywności, że kondycjonowałby akt woli, powodując tym samym nieważność zgody małżeńskiej. Ponadto również w wypadku error facti, a szczególnie kiedy mamy do czynienia z error in persona, o czym mówi kan. $1097 \S 1$, terminologii zastosowanej przez ustawodawcę nie można przypisywać znaczenia obcego tradycji kanonicznej; jak również tylko error in qualitate personae jedynie wtedy może unieważnić zgodę małżeńska, jeżeli konkretna jakość, nie frywolna i nie banalna, zgodnie z kan. 1097 § 2, directe et principaliter intendatur, tj. tak jak skutecznie potwierdziła jurysprudencja rotalna: quando qualitas prae persona intendatur ${ }^{35}$.

W 2009 roku Benedykt XVI - kontynuując magisterium rotalne swojego poprzednika na temat właściwej interpretacji norm kodeksowych - odniósł się do przemówień Jana Pawła II z 5 lutego 1987 roku (Ad Rotae romanae auditores coram admissos, w: AAS 79[1987] 1453-1459) oraz 25 stycznia 1988 roku (Ad Romanae Rotae Auditores simul cum officialibus et advocatis coram admissos, anno forensi ineunte, w: AAS 80[1988] 1178-1185), na temat niezdolności psychicznej, zaznaczając, że jest bardzo ważne, aby po dwudziestu latach od ich wygłoszenia zapytać, jak te przemówienia zostały przyjęte przez sądy kościelne ${ }^{36}$. W szczególności pozostaje sprawą bardzo aktualną w kościelnej praktyce sądowej zapobieganie ewentualnym zgorszeniom, które mogłyby powstać w wyniku rosnącej ilości orzeczeń nieważności małżeństw kanonicznych, przede wszystkim, w sytuacjach ich rozpadu z powodu ,jakiejś” niedojrzałości lub słabości psychicznej małżonka (jednak nie o charakterze patologicznym) - o których to sytuacjach mówił Jan Paweł II w przemówieniu z 1987 roku. Dlatego, jak wskazał Benedykt XVI, jest rzeczą ważną przywołać dzisiaj niektóre rozróżnienia, które wyznaczają linię demarkacyjną, przede wszystkim pomiędzy dojrzałościq psychiczna, która bylaby punktem docelowym rozwoju ludzkiego a dojrzałościq kanoniczna, która z kolei jest minimum dla ważności matżeństwa; po drugie: między niezdolnościq a trudnościq, bowiem „tylko niezdolność, a nie trudność, do wyrażenia zgody małżeńskiej i do realizowania prawdziwej wspólnoty życia i miłości, powoduje nieważność małżeństwa"; oraz po trzecie: między zro-

\footnotetext{
${ }^{35}$ Por. Jan Paweł II, Ad Romanae Rotae auditores coram admissos (die 29 ianuarii 1993), AAS 85(1993), s. 1259.

${ }^{36}$ Por. Benedykt XVI, Ad sodales Tribunalis Romanae Rotae, AAS 101(2009), s. $124-128$.
} 
zumieniem kanonicznym normalności, które inspirując się integralną wizją osoby ludzkiej, „obejmuje także lekkie formy trudności natury psychologicznej", a zrozumieniem klinicznym, które wyłącza ze swojej koncepcji każde ograniczenie dojrzałości oraz „każdą formę psychopatologii”; oraz po czwarte: między „zdolnością minimalną, wystarczającą dla ważnej zgody małżeńskiej” a capacitas wyidealizowaną ,pełnej zdolności w porządku stworzenia szczęśliwego życia małżeńskiego". W dalszej części Benedykt XVI zacytował Jana Pawła II, który w przemówieniu z dnia 5 lutego 1987 roku podał jasną zasadę, według której prawdziwa niezdolność do zawarcia małżeństwa kanonicznego ,jest możliwa do wyobrażenia jedynie w wypadku obecności poważnej anomalii, którą jakkolwiek chciałoby się określić, to musi ona naruszać znacząco zdolność rozumienia i/lub pragnienia kontrahentów". Jednocześnie w swoim przemówieniu Benedykt XVI dodał, że kodeksowa norma na temat niezdolności psychicznej w swoim aspekcie procesowym została ubogacona oraz uzupełniona także przez Instrukcję Dignitas connubii z dnia 25 stycznia 2005 roku, w szczególności Papież odniósł się do art. 209, który należy widzieć w relacji do kan. 1095, n. 1-3. Przywołany artykuł postanawia, że „w sprawach z tytułu niezdolności, według kan. 1095, sędzia nie zapomni zapytać biegłego czy jedna lub obydwie strony, w czasie zawierania małżeństwa były dotknięte jakąś szczególną anomalią habitualną lub przejściową; jaka byłaby jej ciężkość; kiedy, z jakiej przyczyny i w jakich okolicznościach się pojawiła i jak się objawiała. Konkretnie: w sprawach z tytułu braku używania rozumu należy pytać, czy anomalia poważnie zakłócała używanie rozumu w czasie zawierania małżeństwa; z jaką intensywnością i jak się przedstawiała; w sprawach z tytułu braku osądu krytycznego należy pytać, jaki był wpływ anomalii na zdolność krytyczną oraz na możliwość swobodnego decydowania $\mathrm{w}$ przedmiocie podejmowania poważnych decyzji, w szczególności w wolnym wyborze stanu życia; w sprawach zaś dotyczących niezdolności podjęcia istotnych obowiązków małżeńskich należy pytać, jaka byłaby natura oraz ciężkość przyczyny psychicznej z powodu której strona nie tylko ma poważną trudność, ale również niemożliwość realizowania zadań związanych z obowiązkami małżeńskimi”37. Zawarta w tychże przemówieniach tematyka, stanowi - można by tak powiedzieć bardzo istotne zagadnienie współczesnego kanonicznego procesu małżeńskiego i pozostaje przedmiotem wielu sympozjów z prawa kanonicznego ${ }^{38}$.

W ostatnich czasach - zwrócił uwagę Benedykt XVI w przemówieniu rotalnym z 2012 roku - mamy do czynienia z kierunkami, które ostrzegaja przed zbyt wielkim przywiązaniem do ustaw kościelnych, poczynając od

${ }^{37}$ DC, art. $209-\S 1,2$ n. 1-3.

${ }^{38} \mathrm{Z}$ ostatnich wypada wspomnieć zorganizowane przez Wydział Prawa Kanonicznego Papieskiego Uniwersytetu św. Krzyża w Rzymie sympozjum na temat kan. 1095 (26-27 kwietnia 2012), w szczególności na temat rozeznania oceniającego oraz zdolności do podjęcia obowiązków małżeńskich (Discrezione di giudizio e capacità di assumere: la formulazione del canone 1095). 
kodeksów, oceniając je jako manifestację zbytniego legalizmu. Konsekwentnie zostały zaproponowane rozwiązania hermeneutyczne, które prowadzą do takiej innowacji prawnej, że pojedyncza sytuacja stawałaby się czynnikiem kształtującym autentyczne znaczenie obowiązującej ustawy w konkretnym przypadku. Wśród podstaw dla takiej interpretacji należałoby wymienić: miłosierdzie, słuszność oraz „oikonomię” - tak bardzo droga tradycji wschodniej. Wypada jednak szybko zaznaczyć, że takie ukazywanie rozumienia prawa nie pokonuje pozytywizmu prawnego, który w ten sposób odsłania, że interpretacja staje się zasadnicza w ustaleniu tego, co jest jurydyczne. W takim wypadku brakuje poszukiwanego obiektywnego sensu prawa, co prowadzi w konsekwencji do ryzyka popadnięcia w samowolę, ponadto $\mathrm{w}$ ten sposób hermeneutyka prawa zostaje pozbawiona znaczenia, albowiem zanika zatroskanie o poznanie samej dyspozycji prawa: „Zapewne $\mathrm{w}$ takich wypadkach mamy do czynienia $\mathrm{z}$ odniesieniem do fenomenów witalnych, w których jednak nie występuje wewnętrzny wymiar jurydyczny". Istnieje jednak inna droga, na której odpowiednie zrozumienie prawa kanonicznego otwiera drogę do takiej jego interpretacji, która łączy się z poszukiwaniem prawdy oraz sprawiedliwości w Kościele, bowiem słuszne prawo nie może być oddzielone od sprawiedliwości. Wspomniana zasada, na temat której Benedykt XVI mówił podczas swojej wizyty w Parlamencie Federalnym w Berlinie, jest naturalnie obowiązująca także dla prawa kanonicznego, w tym sensie, że ono nie może być zawężone jedynie do systemu normatywnego ludzkiego, ale musi być połączone z porządkiem sprawiedliwości Kościoła, w którym obowiązuje prawo wyższego porządku; dlatego też należałoby powiedzieć, że prawo ludzkie jest o tyle waloryzowane, o ile jest wyrażeniem sprawiedliwości, a przede wszystkim, o ile deklaruje prawo Boże oraz także przez to na ile je wprowadza jako legalne ukierunkowanie prawa ludzkiego. W tym znaczeniu możemy mówić o istnieniu hermeneutyki legalnej, która byłaby autentycznie prawna, w tym sensie, że pozostawałaby w zgodzie ze znaczeniem własnym prawa, tak aby można było stawiać zasadnicze pytanie na temat tego, co jest sprawiedliwe w każdym wypadku. Co ciekawe, Benedykt XVI, podobnie jak jego poprzednik, przywołał także kan. 17 na temat interpretacji kanonów kodeksowych i podkreślił, że wysiłek interpretacyjny, który niekiedy bywa ciężki, nabiera właściwego sensu oraz bezstronności, wówczas gdy pozostaje obiektywny oraz sprawiedliwy. Bowiem zastosowanie środków interpretacyjnych przewidzianych przez $\mathrm{Ko}$ deks Prawa Kanonicznego, zaczynając od słów „,według własnego znaczenia słów, rozważanego w tekście i kontekście", nie może być postrzegany jedynie jako ćwiczenie o charakterze logicznym. W tym wypadku mamy bowiem do czynienia $\mathrm{z}$ zadaniem, które jest ożywiane poprzez autentyczny kontakt z kompleksową rzeczywistością Kościoła, która pozwala na penetrowanie prawdziwego sensu litery prawa; „W ten sposób potwierdza się także poprzez 
hermeneutykę prawa to, że autentycznym horyzontem jest ten związany z prawdą prawną, którą należy kochać, szukać oraz której trzeba służyć”39.

\section{CZY MOŻNA ZMIENIĆ KODEKSOWY EMERYTALNY WIEK PROBOSZCZA?}

Wydaje się, że dotychczasowa analiza zasad interpretacji kanonów kodeksowych daje jednoznaczną odpowiedź, że nie można zmieniać normy powszechnej zawartej w kan. $538 \S 3$, która stanowi, że ,proboszcz, po ukończeniu siedemdziesiątego piątego roku życia, jest proszony o złożenie zrzeczenia się urzędu na ręce biskupa diecezjalnego". Ponadto warto przywołać tutaj merytorycznie dobrze uzasadniony oraz praktyczny komentarz prawno-duszpasterki L. Chiapetty, który analizując przywołaną normę kodeksowa, przeprowadził interesujący wywód prawno-kanoniczny w obronie jej niezmienności ${ }^{40}$.

Na początku wspomniany włoski kanonista wskazał, że kan. 538 § 3 jest normą, która w takiej samej mierze dotyczy kardynałów (zob. kan. 354 rogantur ut renuntiationem), biskupów diecezjalnych (zob. kan. 401 - rogatur ut renuntiationem), biskupów koadiutorów oraz pomocniczych (zob. kan. 411) oraz właśnie proboszczów (gdzie norma kanoniczna stanowi tak samo: rogatur ut renuntiationem). Warto w tym miejscu zauważyć, że możemy w ostatnich latach spotkać się z dość utrwaloną, aczkolwiek nie stosowaną w każdym wypadku praktyką, iż często tak kardynałowie, jak i biskupi otrzymują przedłużenie pełnienia funkcji na powierzonym urzędzie; co więcej, praktyka taka stosowana jest również i względem proboszczów, przede wszystkim w krajach, gdzie brakuje powołań albo mamy do czynienia z wybitniejszą osobowością, która nadal winna służyć lokalnej wspólnocie kościelnej. Norma na temat proboszczów, zresztą jak i wymienione pozostałe, daje takie możliwości, bowiem prawodawca powszechny postanowił: „który rozważywszy wszystkie okoliczności osoby i miejsca, powinien zdecydować o przyjęciu lub odłożeniu zrzeczenia"41. Warto także delikatnie zaznaczyć, że nikt we współczesnej kanonistyce nie dyskutuje, czy obniżyć wiek emerytalny kardynałów z Kurii Rzymskiej, czy też biskupów, jak to ma miejsce w wypadku proboszczów.

Sukcesywnie cytowany autor w swoim komentarzu stawia konkretne pytania oraz udziela rzeczowych odpowiedzi. I tak, pyta, czy może konferencja biskupów lub też biskup diecezjalny zmniejszyć do lat sześćdziesięciu pięciu lub sześćdziesięciu wiek zrzeczenia się urzędu przez proboszcza, $w$ tym celu, aby kanoniczny wiek emerytalny zbiegat się z cywilnym wiekiem

${ }^{39}$ Discorso del Santo Padre Benedetto XVI in occasione dell'inaugurazione dell'anno giudiziario del Tribunale della Rota Romana, w: http://www.vatican.va/holy_father/ benedict_xvi/speeches/2012/january/documents/ (dostęp: 28 X 2012).

${ }^{40}$ Por. L. Chiappetta, Il codice di diritto canonico, dz. cyt., s. 639.

${ }^{41} \mathrm{KPK}$, kan. 538 § 3. 
przechodzenia na emeryturę? W odpowiedzi napisał, że to precyzyjne pytanie zostało już postawione $\mathrm{w}$ ramach prac komisji przygotowującej nowy Kodeks przez jednego z jej członków, który otrzymał odpowiedź: servetur norma, uti factum est pro Episcopis ${ }^{42}$. Stąd też - jak zaznacza Chiapetta należy dostosować się do normy kanonicznej; przy czym zauważył, że nic nie stoi na przeszkodzie, aby konferencja biskupów czy też biskup diecezjalny przyznali proboszczom możliwość wcześniejszego przechodzenia na emeryturę, np. aby w wieku sześćdziesięciu pięciu lat mieli możliwość złożenia takiej rezygnacji, przy czym zaznaczył, że taka ewentualna norma miałaby wyłącznie charakter fakultatywny i należy dodać, że w żadnym wypadku proboszcz po osiagnięciu niekodeksowego wieku emerytalnego nie byłby nią związany, a ewentualne na niego naciski, aby wcześniej, niż przewiduje to norma powszechna, złożył rezygnację z urzędu proboszczowskiego, należałoby uznać nie tylko za nielegalne, ale także i niemoralne. Co więcej, wydaje się, że w takim wypadku mielibyśmy do czynienia z przekroczeniem uprawnień przez przełożonego i mogłoby to skutkować ewentualną sankcją karną, zgodnie z normą kan. 1389 § 1.

Ponadto nasz autor stawia jeszcze jedno praktyczne pytanie: złożenie urzędu w wyniku ukończenie siedemdziesiatego piatego roku życia, tak jak to przewiduje „Kodeks Prawa Kanonicznego” z 1983 roku jest rzeczywiście obowiazkowe? Odpowiadając wskazuje, że należałoby tutaj jedynie mówić o obowiązku moralnym ${ }^{43}$, natomiast ze względu na zastosowany przez ustawodawcę zwrot ,jest proszony (rogatur)" nie można tutaj mówić o obowiązku rzeczywistym oraz własnym i dlatego proboszcz, który po ukończeniu siedemdziesiątego piątego roku życia nie chciałby złożyć zrzeczenia się swojego urzędu, nie mógłby być do tego przymuszony ani karnie, ani administracyjnie przez władzę kościelną. Biskup mógłby pozbawić go urzędu tylko wtedy, jeżeli zachodziłaby jedna z przyczyn kanonicznego usunięcia proboszcza, o których mówi norma kan. 1741. Sukcesywnie dodaje, że jeżeli taka przyczyna by nie występowała, a proboszcz tak pod względem zdrowia fizycznego, jak i psychicznego byłby w stanie poprawnie kierować parafia, nie można go usunąć z zajmowanego urzędu, i dodaje, że biskup za taką sytuację powinien być wdzięczny Panu Bogu (E il Vescovo ringrazi il Signore di poter disporre ancora di un suo sacerdote!). Ponadto wskazał, iż mo-

${ }^{42}$ Communicationes, 1982, s. 227.

${ }^{43}$ Wydaje się, że tak ten obowiązek był rozumiany, przynajmniej czasowo, przez niektórych biskupów polskich, którzy po ukończeniu siedemdziesiątego piątego roku życia nie składali rezygnacji z pełnienia urzędu kościelnego, co spowodowało interwencje nuncjusza apostolskiego w Polsce, który napisał, że „Sekretariat Stanu pismem z dnia 1.12.1990., n. 7571/90/RS, zwrócił uwagę na pewne przeoczenia w przestrzeganiu tego przepisu prawa kanonicznego w Polsce. W piśmie tym Stolica Apostolska prosi mnie o przekazanie Księżom Biskupom następującej informacji: Ta kanoniczna norma winna być przestrzegana przez wszystkich. Każda poszczególna prośba o rezygnację będzie dokładnie przestudiowana przez Ojca Świętego, który w poszczególnych wypadkach podejmie osobista decyzję" (Nuncjusz Apostolski do Biskupów Polskich, „Tygodnik Powszechny” 20 [19 V 1991], s. 9). 
tywacja, że biskup nie może usunąć proboszcza z urzędu tylko z powodu osiagnięcia przez niego wieku emerytalnego, wynika formalnie $\mathrm{z}$ odpowiedzi udzielonej przez Komisję do spraw Interpretacji Dekretów Soboru Watykańskiego II (Pontificia Commissio Decretis Concilii Vaticani II Interpretandis) z dnia 7 lipca 1978 roku $^{44}$; ponadto przypomniał, że podczas Soboru Watykańskiego II pytano, czy wiek może być przyczyna dla usunięcia proboszcza? Udzielona została wówczas krótka odpowiedź: minime $e^{45}$.

W konkluzji należy zatem powiedzieć, że ustawą partykularną wydaną przez niższego ustawodawcę, w tym także poprzez normę synodu diecezjalnego, nie można zmieniać powszechnej normy kodeksowej dotyczącej wieku emerytalnego proboszcza; norma kan. $538 \S 3$ podlega jedynie kompetencji Biskupa Rzymskiego. Oprócz przytoczonych argumentów, pośrednio mówi na ten temat cytowana już Instrukcja Stolicy Apostolskiej o synodach diecezjalnych z 1997 roku, która - wymieniając obszary dla takiego ustawodawstwa synodalnego - pomija przytoczony kanon, gdyż po prostu takie ewentualne ustawodawstwo pozostawałoby poza kompetencjami synodu diecezjalnego i byłoby sprzeczne $\mathrm{z}$ podanymi zasadami. $\mathrm{Z}$ praktycznego punktu widzenia warto także zaznaczyć, że ustawodawstwo różnych konferencji biskupów komplementarne do Kodeksu Prawa Kanonicznego z 1983 roku dotychczas wydało aż pięćdziesiąt jeden różnych postanowień dotyczących kan. $538 \S 1-3$, ale żadne z nich nie dotyczyło zmiany wieku emerytalnego proboszczów; ich przedmiotem pozostawała przede wszystkim troska o socjalne zabezpieczenie emerytowanych proboszczów ${ }^{46}$.

\section{PODSUMOWANIE}

Respektowanie obowiązujących kanonów Kodeksu Prawa Kanonicznego to przede wszystkim uszanowanie woli ustawodawcy kościelnego, w naszym wypadku norm kodeksowych promulgowanych przez bł. Jana Pawła II. Dużą rolę w tym obszarze ma do odegrania metropolita, który sprawuje także funkcję kontrolną w metropolii, której przewodniczy, a którą to funkcję kan. $436 \S 1$, n. 1 określa następująco: „W diecezjach sufragalnych metropolicie przysługuje czuwać nad właściwym zachowaniem wiary oraz dyscypliny kościelnej i powiadamiać Biskupa Rzymskiego o nadużyciach, jeśli jakieś są".

Przedstawiony tekst ma charakter jedynie refleksji na poziomie ogólnym i dlatego nie zawiera on oceny prawnej ani tym bardziej moralnej, co zreszta przekraczałoby jego kompetencje, a należy go potraktować jako włączenie się do zasygnalizowanej na początku dyskusji w polskiej kanonistyce. Zagadnienia tutaj ukazane wymagają jeszcze dodatkowego pogłębienia, ale wydaje się,

\footnotetext{
${ }^{44}$ Por. Communicationes, 1978, s. 159.

${ }^{45}$ Por. Communicationes, 1981, s. 288

${ }^{46}$ Por. J.M. de Agar, L. Navarro, Legislazione delle Conferenze Episcopali complementare al C.I.C., dz. cyt., s. 1364.
} 
że główny nurt doktrynalno-prawny został ukazany, przede wszystkim poprzez odwołanie się do magisterium Biskupów Rzymskich, które stanowi fundament rozwoju prawnej myśli Kościoła i nie może być przez nikogo, ani na poziomie ustawodawczym, ani sądowym, modyfikowane.

\section{HOW TO INTERPRET THE NORMS OF THE CODE? CANON LAW AS A SIGN OF THE UNITY OF THE CHURCH}

\section{Summary}

It is over a quarter of a century since the promulgation of the postconciliar Code of the Canon Law. The past time is characterized by insignificant revisions of the Code legislation introduced both by John Paul II as well as Benedict XVI. Daily life of the Church provides various information that canons of the Code of John Paul II are incessantly interpreted, mainly by judiciary of the Church as well as practice of the diocesan curias and parish offices; naturally it is necessary here to emphasize the considerable and dominant role in applying law by practice of the Roman Curia. Apart from this, it is essential to add the legislative action of particular diocesan bishops and conferences of bishops, among which the Italian Bishops' Conference must be predominantly highlighted. Particular legislation issued by postconciliar particular and diocesan synods cannot be omitted; undoubtedly widely understood postconciliar monastic law also remains a specific collection of the canon law. The article discusses the aspect of an eventual possibility of changing the retirement age of the parish priest by a legislator, mainly by pointing out how to interpret the canons of the binding Code properly. This aspect is examined not unilaterally but in relation to two issues, i.e. regarding canonical marriage process and abovementioned matter concerning the eventual possibility of changing the retirement age of the parish priest. This is a short scientific reflection on the subject of interpretation of the norms of the Code, without critical reference to particular judicial as well as administrative and legal practice.

Keywords:

Roman Bishop, interpretation, unity, particular law, universal law, principles 